\section{$\underset{\substack{\text { hommes } \\ \text { \& migrations }}}{ }$}

\section{Hommes \& migrations}

Revue française de référence sur les dynamiques

migratoires

$1277 \mid 2009$

France - Allemagne

\title{
Frozen River
}

film américain de Courtney Hunt (2009)

\section{André Videau}

\section{Q OpenEdition \\ 1 Journals}

Édition électronique

URL : http://journals.openedition.org/hommesmigrations/189

DOI : 10.4000/hommesmigrations.189

ISSN : 2262-3353

Éditeur

Musée national de l'histoire de l'immigration

\section{Édition imprimée}

Date de publication : 1 janvier 2009

Pagination : 140

ISSN : 1142-852X

\section{Référence électronique}

André Videau, «Frozen River », Hommes \& migrations [En ligne], 1277 | 2009, mis en ligne le 29 mai 2013, consulté le 22 septembre 2020. URL : http://journals.openedition.org/hommesmigrations/189 ; DOI : https://doi.org/10.4000/hommesmigrations.189

Ce document a été généré automatiquement le 22 septembre 2020.

Tous droits réservés 


\title{
Frozen River
}

\author{
film américain de Courtney Hunt (2009)
}

\section{André Videau}

1 Ces immigrés qui viennent du froid, comme leurs frères déshérités en quête d'une vie meilleure sous d'autres cieux, ils sont Chinois, Pakistanais, apatrides... Ils ont payé les yeux de la tête des passeurs sans scrupule et ont risqué leur peau sur des parcours hasardeux. Peut-être ont-ils pensé contourner les difficultés en entrant aux États-Unis, terre promise, par le Canada, terre de transit. Plus précisément par la zone désertique que traverse la rivière gelée du Saint-Laurent qui constitue certes une piste raccourcie et secrète, mais dangereuse. C'est aussi le territoire Mohawk, la communauté indienne dont les ressortissants bénéficient d'une législation spécifique qui les place sous haute surveillance avec une situation juridique hors norme, un mélange d'interdits et de tolérance, de protections et de brimades.

2 Le film de Courtney Hunt, premier long-métrage de cette jeune réalisatrice, nous réserve d'autres surprises que ce dépaysement, ce détournement des chemins et des climats habituels de l'immigration.

3 Ce sont deux femmes, fortuitement réunies, l'Américaine, blanche, - Melissa Leo - et l'Indienne Lila - Misty Upham -, qui vont être au cœur d'un trafic de travailleurs clandestins, passeuses d'occasion et héroïnes.

4 Les hommes, eux, ne sont qu'une bande de truands anonymes, subalternes et menaçants, qui regroupent les fuyards, s'assurent de leur solvabilité, les enferment dans des coffres de voitures et, pour ainsi dire, passent la main à leurs complices.

Quand elles s'obligent à faire équipe, leur situation n'est pas brillante. La contrée n'offre pas de débouchés aux femmes seules. Lila est une mère célibataire qui vivote misérablement dans la réserve, victime du chômage endémique dans sa communauté, et de plus, handicapée par une vue déficiente. Ray, serveuse d'un minable drugstore, a la charge de ses deux enfants depuis le départ de son mari avec leurs économies : un adolescent fragile et une fillette à qui elle rêve d'assurer des conditions de vie décentes hors du préfabriqué délabré qui prend l'eau et le gel de toutes parts. Peu de chance 
d'acquérir un confortable mobile home avant Noël qui approche, même pas de faire des cadeaux!

6 L'occasion de s'en sortir ne se présente pas sans violence et sans déchirement de conscience, mais dans une morale sommaire, on peut considérer que l'acte délictueux n'aggrave pas la misère des plus misérables. Les deux femmes s'adonnent à leur trafic, profil bas. La prise de risque est une sorte de punition.

7 Le film, qui avait commencé comme un documentaire, tourne au thriller d'une beauté glacée et nocturne, et tient la route, surtout grâce au jeu puissant des deux comédiennes. 